\title{
A Prediction of The Effect Of Climatic Anomaly on Lake Beratan Ecosystem in Bedugul High Land, Bali
}

\author{
Dewa Made Atmaja \\ atmajadewamade@yahoo.com \\ Universitas Pendidikan Ganesha, Indonesia
}

\begin{abstract}
As one of land waters ecosystem, lake has various functions which support human life. The role of Lake Beratan with its multifunctions and uncontrolled use have caused problems which threaten very much the ecosystem of the lake. Climatic anomaly is predicted to give pressure to the environment of the land waters environment that has caused changes beginning from its productive capacity, water quality and quantity to water related disasters in the decade to come. The aim of this study was to find out how the climatic anomaly will affect Lake Beratan ecosystem. This study was a descriptive qualitative one using a survey method, the data in the form of primary and secondary data. Related to this phenomenon, there is a need for a high predictive ability of the effect which the climatic anomaly causes on all aspects of life, including lake Beratan ecosystem. This predictive ability can be acquired with sufficient knowledge about climatic anomaly and the process that occurs in Lake Beratan ecosystem. This condition becomes a valuable asset in doing a comprehensive study to anticipate the effect of the anomaly. The effect that arises is the degradation of Lake Beratan Functions since the water quality worsens, the sedimentation is high, so that the lake volume becomes smaller, the growth of colli bacterium increases and 2 fish species have become extinct
\end{abstract}

Keywords: Climatic Anomaly, Lake Beratan, Ecosystem

\section{Introduction}

Among today's hot issues is climatic anomaly. In principle, climatic anomaly is a phenomenon of global warming from year to year due to the greenhouse effect caused by the increase in the emission of gasses such as carbon dioxide (CO2), methane ( $\mathrm{CH} 4)$ dinitrooxide (N2) and CFC which trap the solar energy in the earth atmosphere. Scientific findings reveal that human activities contribute to the global warming since the middle of the $20^{\text {th }}$ century. The global warming will continue to accelerate at a higher rate in the $21^{\text {st }}$ century if no effort is made to reduce it. The global warming causes climatic anomaly and increase in frequency and intensity of the climate becomes extreme.

Lake Beratan is a surface water resource which is ecologically very important since it holds the rainwater in Bedugul high land. Economically, the role of the lake is very vital, since it has various functions as water resource for the surrounding community for drinking, agriculture, fishery, and as a tourist resort (Atmaja, et al. , 2017). The existence of Lake Beratan gives important benefits to the environment, especially as a hydrological link, beside a source of income for the regency through the tourism sector. On the other hand, the increase in economic activities, both the tourism sector, industrial sector and agricultural sector have caused various problems such as the damage to the watershed areas, environmental 
pollution, the shallowing of the lake and erosion (Arsyad, 2012). The risky activities that have caused the lowering of the lake water resource quality are the dumping of hotel waste, household waste, agricultural waste, and water transport fuel waste. In addition, attention has to be focused on the the use of land in the water resource boundaries that has caused environmental degradation ( Mustapha, 2011: Omondi et al, 2014).

Today Lake Beratan gets a heavy pressure, i.e., a high sedimentation, domestic waste pollution and the reasonably rapid growth of a fishery practice using floating fish cages (Hehanussa, 2005). Based on the result of an Quickbird satelite image in 2005, the area of Lake Beratan water surface was 3,827 sq. km, while the result of the analysis of Quickbird satellite image in 2014 showed that the surface water area was 3,764 sq. km. Within the 9 years period there had been a reduction of the lake of 0.063 sq. km. ( $1.65 \%$ ) and this automatically reduced the lake water volume due to sedimentation. The sedimentation was triggered by a high rainfall, young land structure, and damage caused by land use in the catchment areas of Lake Beratan. The impact of this problem is the damage to the habitat of the lake waters which caused a reduction in its biodiversity (Atmaja et al, 2017). The effort to protect the lake waters environment needs to be made, and this covers the effort to improve the lake waters environment as the resource of various biota habitats and to control of the rate of sedimentation.

The land waters area that belongs Lake Beratan ecosystem is the support for human life in meeting his or her life needs today and in the future, since the lake ecosystem, as other land waters ecosystems, provides daily needs, a source of protein, minerals, and energy, means of transportation, and a tourist resort (Gadis, 2009). Climatic anomaly will influence the capacity of the lake in supplying productive resources for humans. The aim of this study was to find out how climatic anomaly effects Lake Beratan ecosystem.

\section{Methodology}

This study was conducted in Beratan ancient volcanic caldera of Bedugul high land by using an ecological approach. The method used in this study was a survey method, using an instrument in the form of a closed questionnaire. The data, both primary and secondary data, that were collected were in the form of hydro-climatological aspect, waters physic chemical biological aspects, and socio-economical aspect. The data were analyzed with a descriptive qualitative analysis.

\section{Result and Discussion}

\section{Effects on Physical Characteristics of Lake Baratan}

\section{Basin Integrity}

The effects of the climatic anomaly are among others: increase in air temperature, change in dry season length, which make the volume of surface water smaller, and this condition is worsened by an increase in air temperature which increases evaporation, which in its turn will threaten the availability of surface water ( lakes, dams, and swamps). On the other hand, a short rainy season causes part of the rainfall which forms surface water runoff to become 
increasingly broader since the intensity of the rain increases. So during the rainy season the surface water condition increases drastically and even causes flood in some areas.

Changes in the system of the pattern of the rainfall and season have the potentiality to shift the lake connectivity. When the connectivity is broken very seriously then the ecosystem will be disturbed, which causes a decrease in fishery productivity. The characteristic of TNDS is a seasonal lake whose water depends on rainfall and river water flow. Lake and river have a functional unity, if the river surface water decreases the lake water will flow into the river and if the river water increases, then it will enter the lake area. The lake sentarum undergoes wet and dry phases because of the effect of the rainfall in the river upper course. The lake water will flow into the river at the time the monthly rainfall $<250 \mathrm{~mm}$. The dry phases occurred in 1999 - 2004.

\section{Water Balance}

The decrease in rainfall as the input of the component variable of watershed caused by global climatic anomaly will influence the river water debit and influence the water level of Lake Beratan which generally receives water from the river flow. The climatic anomaly influences the annual total river water flow and seasonal dynamic. In general, the effect is very simple, that is a higher rainfall will produce more rainfall and a lower rainfall will reduce the river water flow. However, the correlation between the river water flow change and the waterfall is very different in a different area with a different climate (Ludwig, 2009).

The shift in precipitation $(\mathrm{P})$ is relative to evaporation $(\mathrm{E})$ which causes a change in water budget and the length of stay of Lake Beratan water, like its depth and width. Ponds and wet land are specially very susceptible to the change in P/E because of their shallow depth and the ratio of the width to the volume. An example is Lake Chad with a depth less than 7 $\mathrm{m}$. It has undergone changes caused by climatic warming in the areas in some recent decades (Vincent, 2009). Since 2005 a decrease in rainfall has caused the decrease in the area of Lake Beratan from 3.85 sq. $\mathrm{Km}$ to 2.74 sq. $\mathrm{Km}$ in 2015 as the effect of the climate and the increase in the need for drinking water during the dry condition.

The hydro-climatologic data show a high correlation between the lake surface water level and the rainfall in the catchment area. The annual fluctuation of Lake Beratan water in dry months is $+0.37 \mathrm{~m}$ and $-0.27 \mathrm{~m}$ or the average fluctuation is $0.74 \mathrm{~m}$, while in the wet months it is $+0.63 \mathrm{~m}$ and $-0.67 \mathrm{~m}$ or the average of the fluctuation is $1.30 \mathrm{~m}$. The highest inflow occurs in February $(1.02 \mathrm{cubic} \mathrm{m} / \mathrm{sec})$ and the lowest is in September $(0.03 \mathrm{cubic} \mathrm{m} / \mathrm{sec}$ or the average is 0.37 cubic $\mathrm{m} / \mathrm{sec}$ ). The highest outflow occurs in February ( 0.97 cubic $\mathrm{m} / \mathrm{sec}$. and the lowest in November $(0.13$ cubic $\mathrm{m}$ or the average is $0.34 \mathrm{cubic} \mathrm{m} / \mathrm{sec})$. The highest storage occurs in December $(0.50$ cubic $\mathrm{m} / \mathrm{sec})$ and the lowest is in April ( 0.09 cubic $\mathrm{m} / \mathrm{sec}$ or the average is 0.03 cubic m/sec . (Atmaja et al., 2018). More specifically this can be seen in Figure 1 below. 


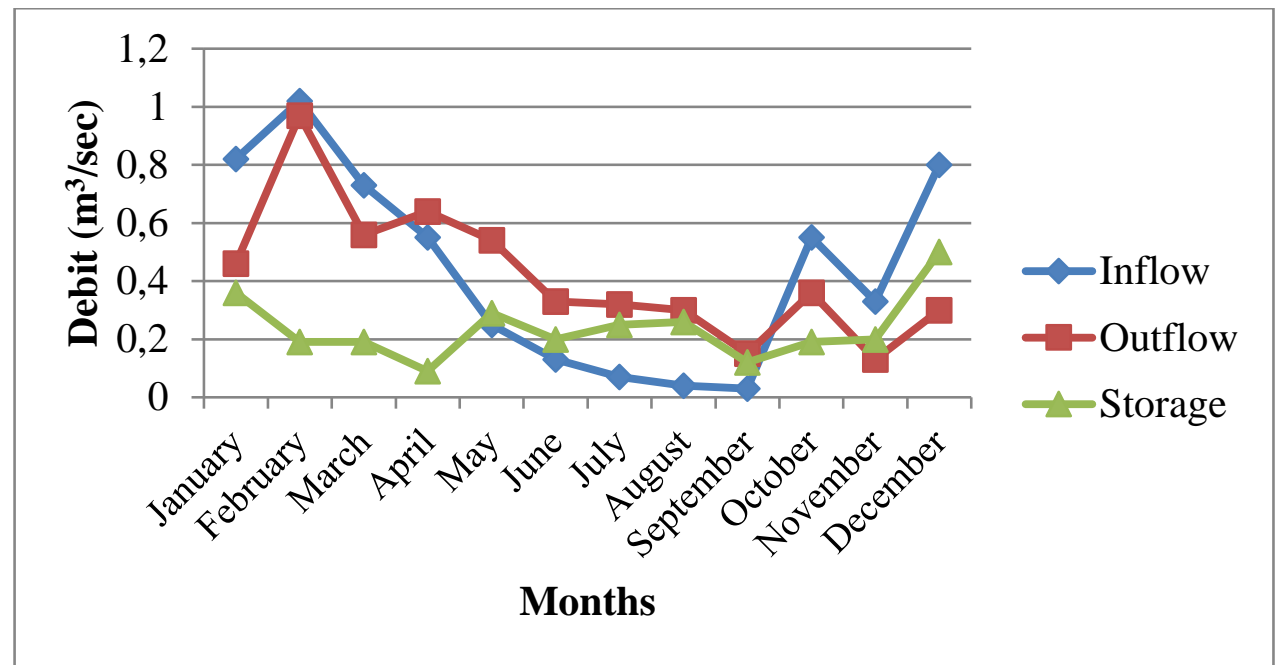

Fig 1. Water Balance in Lake Beratan.

3. Temperature and stratification.

A warmer air temperature will warm up surface water through conduction which transfers heat. Although this will be followed by an increase in the speed of evaporation, The effect of lake stratification is also assumed to be influenced by climatic anomaly. The effect is felt in the thickness and shift of termoklin layer, and the rate and speed of gas solution in the water. Based on the result of the study of Lake Beratan, the writer found a stratification of $0.65^{\circ} \mathrm{C}$ and the average temperature reached $23^{\circ} \mathrm{C}$. To what extent is the effect of climatic anomaly and the increase in global temperature on the shift of termoklin layer in Lake Beratan, Bali, Indonesia? To answer the question an in-depth study is still needed.

\section{Sedimentation Rate}

A lake or a river or the like becomes shallow because of sedimentation as the accumulation of fragments from an erosion. The erosion fragments accumulation which is hooked by the water current will precipitate when the strength of the water current weakens. The total sediment comes from suspension product, total dissolved solids ( TDS) and precipitated sediment. Based on the measurement, precipitated sediment does not have a significant contribution to lake bed silting because the sediment comes from the lake wall collapse. The condition of all walls of the lake was good and was solidified with stone piles.

Precipitated particles have a spread close to their source, because the transfer that occurs is influenced by the power of the transportation. Hence, the further they are from their source the finer and the less they are (Chamley, 1990; Walter et.al. 2014). This also occurs at the bed of the lake, the more it is to the center the finer it is. The lake bed is higher at the edge.

The total amount of sediment accumulated in Lake Beratan is the amount of TDS and the suspension product in 7 months. The total amount of the sediment can be seen in table 1 as follows 
Table 1. The Total Amount of Sediment in Lake Baratan in 7 Months

\begin{tabular}{lllllll}
\hline $\begin{array}{l}\text { Channel that } \\
\text { enterr the } \\
\text { lake }\end{array}$ & $\begin{array}{l}\text { Suspensio } \\
\mathrm{n} \text { product } \\
(\mathrm{Kg})\end{array}$ & $\begin{array}{l}\text { TDS } \\
\text { Product } \\
(\mathrm{Kg})\end{array}$ & $\begin{array}{l}\text { Total } \\
\text { sedimen } \\
\mathrm{t}(\mathrm{ton})\end{array}$ & $\begin{array}{l}\text { DTA } \\
\text { area } \\
\text { (ha) }\end{array}$ & $\begin{array}{l}\text { Total } \\
\text { sediment } \\
\text { (ton/ha/year } \\
)\end{array}$ & clasification \\
\hline Channel 1 & 18,952 & 4,510 & 23.462 & 49.91 & 0.47 & $\begin{array}{l}\text { Very light } \\
\text { Channel 2 }\end{array}$ \\
\hline 11,837 & 4,160 & 15.997 & 28.52 & 0.56 & Very light \\
Channel 3 & 15,333 & 4,258 & 19.591 & $42 ` 78$ & 046 & Very light \\
Channel 4 & 6,690 & 4,164 & 10.854 & 21.39 & 0.51 & Very light \\
\hline Total & 52,812 & 17,092 & 69.904 & 142.6 & 2.00 & Very light \\
\hline
\end{tabular}

Source : The Result of computation

The total sediment accumulated in Lake Beratan which comes from channels 1,2,3 and 4 fall into a very light classification. This means that the classification used does not fit the young volcanic region. This is due to the absence of a channels system that functions as the sediment collector and distributor which can be used to measure sediment directly as the response of the erosion product to the rain. In addition, the runoff that occurs in Lake Beratan is smaller from that in the non-volcanic land, since like what generally occurs in the volcanic area most of the rain water loses and transforms into ground water through infiltration process. However, the sediment product accumulated in Lake Beratan is significantly numerous at 69.904 ton/year. The similar thing occurs too in the study conducted by Yumi (2001) and Walter et.al (2014). The mismatch of the sediment classification which is caused by the absence of a channel system which functions as collector and distributor of sediment which can be used to measure sediment directly as the response of erosion product to the rain.

Channel 1 has a great amount of sediment which comes from suspension, in the form of colloid particles because of the abundance of algae in Lake Beratan. If the lake is free from algae then the total sediment becomes slow. The amount of total sediment in Channel 1 is also caused by the fact that Channel 1 has the greatest catchment area compared to the other channels. In addition, the slope of Channel 1 ranges from 0 to $45 \%$, while those of the other channels range from 0 to $30 \%$. Based on this it can be estimated that a higher power of transportation and the erosion of runoff occur in the catchment area of Channel 1.

Land use and conservation are practices in the physical environment which can influence human activities. Land use is related to the function to protect land from the damaging effect of rain, in addition plant spesies also influence the crop value. Conservation action can take the form of terrace construction, but this action is not taken in the steep slope in the forest land and Channel 1 so that the runoff moves quickly carrying the material from the erosion to the body of Lake Beratan.

The classification unit used was in ton/ha/year unit, while in this study the data were collected in the rainy season in seven months, but the classification has continuously been used. This is based on the assumption that has been made, that is the addition of suspension only occurs in the rainy season, since in dry season the rain which falls is regarded to have not enough strength to transport the erosion product. From the result of computation in the four channels that enter the body of Lake Beratan as the sample it was obtained that the sedimentation rates were not so serious, since all fall into very light classification or less than 14.6 ton/ha/year.

\section{The Effect on the Chemical Characteristics of Lake Beratan}


The most basic thing is that the more frequent the heavy rain falls will cause the transportation of contaminants and sediment into Lake Beratan. Therefore, the pollution from agriculture and other sources will worsen the pollution in the lake. However, an increase in the water flow during the rainy season will make the pollutant thinner and will improve the water quality.

The length of stay of water in the lake that influences the lake water chemical composition by regulating the time available to make the biogeochemical and photochemical processes last, to prolong the accumulation and loss of dissolved material, particulate material, and the duration of biogeochemical interaction with the sediment of lake Beratan and littoral region. In the lake which usually has the bed with anoxic condition and nutrient release from sediment, the length of stay of water which is caused by the reduction of precipitation and the inflow will cause phosphor accumulation and eutrofication.

The evaluation of lake water quality in the research region using group A quality standard was done for every parameter observed, then the result was converted to drinking water standard (see Sutikno, 1989), in which good (B) water quality indicates that all of the physical, chemical and bacteriological characteristics meet drinking water standard requirement, medium $(\mathrm{S})$ water quality indicates that there are some physical, chemical and bacteriological characteristics which do not meet drinking water quality requirement directly, but it can still be overcome by a simple processing, bad (J) water quality indicates that many physical, chemical, and bacteriological characteristics do not meet drinking water standard requirement and difficult to be overcome with a simple processing.

The water physical characteristics such as color, taste and odor in this study did not use quantitative measurement which met the group E water quality standard requirement. Then other parameters : Ph turbidity, electrical conductivity and the amount of dissolved solid in this study used quantitative measure for all water sample which also met the A group water quality standard, accept $\mathrm{Ph}$ element in a $10 \mathrm{~m}$ depth and bed $(20 \mathrm{~m})$ did not meet the A group requirement but met the $\mathrm{B}$ group requirement.

The chemical characteristic of lake water whose sample was analyzed met the A group water standard, except the heavy metal element, or $\mathrm{Pb}$ in the second, third and fourth points the content was above the threshold level of the A group requirement. The high level of $\mathrm{Pb}$ content in the three sample points was caused by the use of Jetsky, Motor boat and motorized vehicles.

The most stable and long lasting lake stratification will cause chemical variable gradient to descent to water column. In the lake which undergoes nutrient enrichment, this can trigger a shift from oxygenization condition to anoxic condition in the bed of the lake and by exceeding this limit there will usually be an increase in nutrient concentration for algae, including the availability of phosphor and various toxic components, especially $\mathrm{H} 2 \mathrm{~S}$, the anoxic condition also promote the loss of nitrogen from the ecosystem through denitrification process (Vincent, 2009). The effect of climatic anomaly on lake water quality depends very much on the evolution in human activities in the future.

\section{The Effect on the Lake Biological Characteristics}

All of the ecosystems are threatened by climatic anomaly, but the aquatic ecosystem is one the ecosystems which have a large number of species under the threat. Many wet lands with a biodiversity assset undergo changes in rainfall which will disturb the hydrology, and accelerate the damage (Ludwig, 2009). The varied precipitation system will cause a change in water 
availability in the ecosystem. An increase in water temperature is an important effect on the lake ecology and its biological community. Changes in temperature will influence the ecosystem function especially when it interacts with chemical pollutions. When warmer water associates a superfluous nutrient which comes from the agricultural fertilizer in the catchment area, then eutropication will occur and cause an explosion of plankton growth in lake Beratan surface, which will automatically lowers dissolved oxygen concentration (DO), which will endanger the life of other organisms in the lake ecosystem (Jeppesen et. al. 2007).

Changes in the available light and nutrient because of the climatic anomaly has an effect on the composition and diversity in the level of primary producers which in turn will influence a high trophic level. Changes in Lake Beratan will influence the composition of species in macrophysics community in the litoral zone that has an implication on birds, fish and other biotas who depend on the existence of the plants. Many fish species are sensitive to a change in temperature, although the change is small.An increase in temperature caused by global warming is suspected to cause a shift in geographical distribution of various taxa. Climatic anomaly also influences migration habits of various fish species because of the changes in rain water pattern system and seasons which has as an implication on the shift in connectivity in Lake Beratan.

\section{Conclusion}

Climatic anomaly will give an additional pressure to a number of pressures that exist on lake Beratan ecosystem. Loss in terms of long term economy will be greater if no effort is made to reduce the effect of climatic anomaly and other anthropogenic activities which cause a reduction in Lake Beratan ability to use its ecological functions. The process which affects the damage to Lake Beratan ecosystem tends to become more complex so that its solution requires integration with other disciplines by synergizing various knowledge and technologies one can predict the possible anomaly that will occur. Climatic anomaly that occurs in Lake Beratan has an impact on an increase in water temperature which will cause a greater fluctuation of the water of Lake Beratan. Qualitatively, changes in some parameters, which have decreased the quality of the water, are apparent, especially in the drastical increase in the population of Coli bacterium and $\mathrm{Pb}$. To solve the problem the government should develop an information network.

\section{References}

[1] Atmaja Dewa Made. Sri Budiastuti. Prabang S. Sunarto. 2017. Sediment Characteristics and Benthos Community Spread in Lake Beratan in Bali. Proceding Advances in Social Science, Education and Humanities Research, volume 79, pp. 76-80. 1st International Conference on Geography and Education (ICGE 2016). Atlantis Press.

[2] Atmaja Dewa Made. Sri Budiastuti. Prabang S. Sunarto. 2018. An ecohydrological-based management of Lake Beratan in Bedugul, Bali. IOP Conf. Series: Earth and Environmental Science 148 (2018) 012024. doi :10.1088/1755-1315/148/1/012024

[3] Chamley H., 1990. Sedimentology, University of Lille. Villeneuved' Ascq.

[4] Gadis, Haryani, 2008. Inland Water and Climate Change. International Workshop on Climate Information Services in Supporting Mitigation and Adaptation to Climate Change in

Energy and Water Sectors. Jakarta. BMKG. 
[5] Jeppesen, E., Meerhoff, M., Jakobsen, B.A., Hansen, R.S., Sondergaard, M., Jensen, J.P., Lauridsen, T.L., Mazzeo, N., Branco, C. 2007. Restoration of Shallow Lakes by Nutrient Control and Biomanipulation. The Successful Strategy Varies with Lake Size and Climate. Hydrobiologia 581(1): 269-285.

[6] Ludwig, F \& M. Moench. 2009. The Impact of Climate Change on Water in Climate Change Adaptation in the Water Sector. Eds. Ludwig, Pavel Kabat, Henk Van Schaik \& Michael Van Der Valk. 274 p.

[7] Sutikno. 1989. Kajian Bentuk Lahan untuk Pemerintahan Sistem Penyediaan Air Bersih di DAS Serang Kulon Progo. Yogyakarta. Laporan Penelitian. Fakultas Geografi UGM.

[8] Vincent, W.F. 2009. Effects of Climate Change on Lakes. Elsevier Inc. 55-60 p.

[9] Walter Finsinger, Thierry Fonville, Emiliya Kirilova, Andrea Lami, Piero Guilizzoni, André F. Lotter. 2014. A long-term multi-proxy record of varved sediments highlights climateinduced mixing-regime shift in a large hard-water lake 5000 years ago. Journal of $\begin{array}{lllll}\text { Limnology } & \text { Vol 73(2): 211-222, } & \text { eISSN } & 1723-8633 .\end{array}$ http://dx.doi.org/10.4081/jlimnol.2014.907.

[10] Yumi Lestari. 2001. Karakteristik Muatan Suspensi Pada Danau Doline Di Kecamatan Ponjong Kabupaten Gunung Kidul. Laporan Penelitian (tidak dipublikasikan). Universitas Gadjah Mada; Yogyakarta. 